\title{
䣿 $\mathrm{K} \alpha \gamma \mathrm{Q}^{1}$ \\ Kaygı Uludağ Üniversitesi Fen-Edebiyat Fakültesi Felsefe Dergisi \\ Uludağ University Faculty of Arts and Sciences Journal of Philosophy \\ Sayı 27 / Issue 27| Güz 2016 / Fall 2016 \\ ISSN: 1303-4251
}

Research Article

Araştırma Makalesi

Olanrewaju Abdul SHITTA-BEY ${ }^{1}$

Dr. Dr.

Post-Doctoral Research Fellow: Department of Philosophy, Uludag University, Bursa - Turkey

Lagos State University, Faculty: Department of Philosophy, Lagos - Nigeria

tilewa02@yahoo.co.uk

\section{A Discourse on the Ontology of Violence}

\begin{abstract}
The sophistication and reoccurrence of violence has continued to gain increasing attention in contemporary discourse. Scholars that take interest in the study of violence have made efforts only in understanding and addressing the causes, forms, and the management mechanism. Such intellectual efforts have proved not to be sufficiently adequate as evident by the recurring decimal of violence in limitless proportion, even in places where it has been under-studied. This inadequacy has made the need for renewed interest in the study of the nature and dynamics of violence imperative. Concerned about the lack of consideration for the ontological root of violence in previous studies, this paper seeks to critically explore the ontology of violence. It aims at examining classical philosophical texts on human nature with a view to expose the ontological origin of violence and shows how such consideration is apt in the understanding, addressing, and management of violence; that is, this paper makes a case for the study of the ontology of violence as a way of addressing the lacuna currently existing in the studies on violence. Thus, it argues that this ontological study entails as a matter of necessity an understanding of human nature in relation to the subject-matter of violence. The methodology used in achieving the aim of this paper is the analytic and phenomenological approaches, that is, analysis and phenomenological examination of textual materials are employed by the study.
\end{abstract}

\section{Keywords}

Violence, Human nature, Desires, Ontology, Plato, Hume, Hobbes.

1 This work is the outcome of the Post-Doctoral Research Fellowship funded by the Turkiye Scholarships in the Department of Philosophy at Uludag University (27th January-28th July 2016), and it enjoys the support of Prof. (Dr.) Abdulkadir ÇÜÇEN as Advisor. 


\section{Introduction}

The phenomenon of violence has a multi-dimensional occurrence in human interactions that can be identified in different experiences: intra-personal, inter-personal, intra-group, inter-group, as well as personal-group. Respectively, this means that violence is exhibited by an individual against self; by an individual against another; by a set of individuals against another set of individuals that share either or all of the same tradition, skin colour, values, and so on; by a set of individuals against another set of individuals that differ in either or all of religious creed, cultural values, and so on; and can be exhibited by an individual (or set of individuals) against an entire group of individuals or vice versa. Given that the phenomenon of violence occurs without any straightjacket pattern or form, understanding and addressing it poses significant problems. This is evident in the works of scholars like Gellner, Keane, Armstrong, William de Haan, Payne, Ganley, and Friedman on the phenomenon of violence.

It is in this regard that this paper critically examines the works of some of these scholars to acquaint us with the difficulty of understanding the convoluted existence of violence. In addition, the paper interrogates important texts on human nature with the aim of demonstrating the ontological root of violence. The paper primarily seeks to argue the difficulty with having an adequate understanding of violence as resulting from the little or no attention given to the ontological root of violence.

The paper is in four sections excluding the introduction. The section that follows the introduction is titled "Defining Violence", and this presents an encompassing meaning of violence that relies upon the common denominator that is drawn from various definitions and conceptions of violence in available texts. The reason for this is simply to have a clear working understanding of the term.

The section following it is titled "On Variations of Violence", and it attempts an overview appraisal of the various forms and/or typologies of violence. Beyond conceptual analysis, this section seeks to explore more deeply the notion of violence in its numerous dimensions. This is simply to demonstrate the variations that the phenomenon of violence is capable of taken as well as the enormity of its present variations.

The next section is titled "The Ontology of Violence"; and in the section, the essay focuses on the works of classical thinkers especially those that have expended efforts and thoughts to understudy human nature. This is to show that violence has its ontological root in human nature, and that this is most important in any attempt to understand and address the problem of violence adequately. Specifically, the section examines the important classical works of Plato, David Hume, and Thomas Hobbes as well as a couple of other significant materials where and when necessary.

The last section is the "Conclusion", where the essay presents a conclusion of the discourse. The purpose is to re-emphasize that the difficulty associated with studies on violence is due mainly to the little or no attention paid to the ontological rootedness of violence in human nature. The paper remarks with a hint on culture as an instrument through which violence in its varying dimensions can adequately be understood and managed. 


\section{DEFINING VIOLENCE}

Definition should play the significant function to eliminate ambiguity that may be associated with any notion (or idea, term, concept and so on). That is, definition should ensure that notions are rendered simple and unambiguous. With definition, there should be the guarantee that the basic information that undergirds any notion would be adequately established for the purpose of enhancing our understanding.

There are numerous definitions of violence as there are numerous instances of it. The need to have an encompassing working definition of it, for the purpose of our task in this essay, demands that we examine some of these meanings. In other words, an examination of some of the meanings of violence as put forward by numerous scholars will not only serve to provide grounds for an encompassing definition, but would also enrich the working definition that we seek.

In defining violence, there is more ambiguity than simplicity because there is hardly a precise definition of the concept in the numerous texts on it. The free-for-all uses of the term make it much more difficult to define; that is, the term is subjected to various and different uses such that it is difficult to sift a common or basic assumption that undergird them, and that can inform the comprehensive meaning so desired.

This problem results from various historical and contextual uses and abuses of the term. The historical and contextual development of the term is replete with various, often ambiguous, uses and abuses. This claim is noted by Keane (2004) when he writes that:

Like all concepts in the human sciences, categories like violence are as dangerous as they are necessary. They can be fatal for the imagination, in that they lull their users into a false sense of certainty about the world, seducing them into thinking that they 'know' it like the backs of their hands...The task of clearly defining violence is complicated by the fact that...the term itself has undergone a definite 'democratisation', by this, it means three things. [1] The scope of application of the term 'violence' has been broadened; [2] its meaning has come to be seen as heavily contextdependent and, hence, as variable in time and space; [3] in consequence,...the term 'violence' and its negative connotations are now notoriously contested in such fields as criminal law, journalism, public policy and everyday life. It is vital to take note of this democratisation process, if only to offset the bad habit of some historians, who use the term imprecisely and anachronistically (30$31)$.

The complexity involved in the uses and abuses of the term is further identified by North, Wallis, and Weingast (2009) when they note that the manifestation of the phenomenon in various dimensions poses serious difficulty to the task of articulating a definite definition of the term. According to these authors:

Violence manifests itself in many dimensions. Violence can be expressed in physical actions or through coercive threats of physical action. Both violent acts and coercion are elements of violence. The relationship between violent acts and coercion involves beliefs about the actions of others, and we pay considerable attention to whether threats of violence are credible and the conditions under which the use of physical violence will result in 
response from other individuals or from the state. On another dimension, violence may be the action of a single individual or the action of organized groups ranging from gangs to armies (13-14).

As an example, Kalyvas (2006) defines violence as "the deliberate infliction of harm on people" (19). To define violence in this manner is too vague because it excludes the entity or entities that are inflicting the harm on people; it also assumes that violence is necessarily a deliberate act, and that harm is functional bad. Also, Mayer (2000) considers it as "a political, legal, and cultural construction that merely forces attention to the identity of those engaged in the construction and to their reasons, procedures, and intentions" (73). This consideration is restrictive for limiting violence as a political, legal, and cultural construction, though interesting for pointing at 'intentions'.

Notwithstanding the problematic shown above, it is very possible to come up with a concise definition of violence which is fairly encompassing enough to accommodate the different uses of the term. Against this backdrop, the term 'violence' denotes the act exhibited by human (as an individual or group of individuals) to dehumanize the self and/or the others.

Each word in the definition above is carefully chosen to avoid ambiguity. The word 'denote' implies that the term describes, hence, the term is descriptive - of a situation, an event, or an occurrence. The expression 'the act' signifies an action and a threat, which means that it can either be an action, a threat, or both. The word 'exhibit' entails potentiality hence it can be intentional or non-intentional, physical or nonphysical. The notion 'human' is used to situate the focus of interest on the human world as against the non-human world. And finally, the word 'de-humanize' connotes undesirable experiential human condition(s).

From this perspective, it is obvious that our working definition as explicated above is wary of the democratization process that Keane talks about, and it is not to offset the bad habits of the historians only, but also to offset the bad habits of the experts and scholars that use the term imprecisely and anachronistically. In addition, the definition is encompassing enough to accommodate the manifestations of the phenomenon in its various dimensions as noted by North et. al. With this suitable definition, we move to the next section where we consider an overview of the variations of violence.

\section{ON VARIATIONS OF VIOLENCE}

This section examines the forms and typologies that violence has taken as well as it is capable of taking. Willem de Haan (2008), in his "Violence as an Essentially Contested Concept”, provides us with significant, broad, and handful insight that captures the forms and typologies of violence. According to him, violence as a phenomenon is multifaceted; in explaining what this means, Willem de Haan states some of the forms and typologies of violence. The author writes that:

Violence is multifaceted because there are many different forms of violence, ...it can be distinguished in 'youth violence', 'gang violence', 
'school violence', 'street violence', ‘teen violence', 'dating violence', 'intimate violence', ‘domestic violence', 'workplace violence', 'suite violence' ... 'urban violence’, ‘interpersonal violence’, 'random violence', 'racist violence', 'media violence', 'mimetic violence', 'systemic violence', ‘symbolic violence’, ‘structural violence’ or even ‘apocalyptic violence’ (28).

From Willem de Haan's submission, it means that violence has many forms and it is capable of taking many more for as long as human existence do not seizes. However, some of these forms of violence overlap only to create a bogus list of variations of the phenomenon, and sometimes it is only a matter of technicality that multiplies the list. A look at two or more examples will explain this better.

Domestic violence, for instance, is defined as "a pattern of assaultive and coercive behaviors, including physical, sexual, and psychological attacks, as well as economic coercion, that adults or adolescents use against their intimate partners" (Ganley, 2016: 16). "Domestic violence has many names: wife abuse, marital assault, woman battery, spouse abuse, wife beating, conjugal violence, intimate violence, battering, and partner-abuse. Sometimes these terms are used interchangeably to refer to the problem, while at other times a particular term is used to reflect a specific meaning” (ibid). As a particular variation of violence thus, domestic violence also encompasses all manners of violence that occur among intimate members of a household regardless of the venue of space and location where the violence occurs.

Youth violence is another example, this is used interchangeably sometimes with gang violence, gun violence, or organized crime. And it is defines as "harmful behaviors such as bullying, slapping, or hitting that can start early and continue into young adulthood. The young person can be a victim, an offender, or a witness to the violence" (see CDC, 2016). There is also interpersonal violence, which is define as "the intentional use of physical force or power, threatened or actual, against another person or against a group or community that results in or has a high likelihood of resulting in injury, death, psychological harm, mal-development, or deprivation” (Dahlberg and Krug, 2002: 3).

Another example is structural violence. According to Rutherford, Zwi, Grove, and Butchart (2007), structural violence incorporates and breeds other variations of violence. This understanding is made clear in their submission that,

"Structural violence" refers to the physical and psychological harm that result from exploitative and unjust social, political and economic systems. The apartheid system, based on racial discrimination in South Africa, is a classical case of structural violence in which the state set in place unjust laws and systems which disempowered, marginalised and disenfranchised the majority black population. These and related human rights violations are significant social determinants of ill health. Furthermore, Structural violence is, however, often most pervasive because of its invisibility: 'embedded in ubiquitous social structures (and) normalized by stable institutions and regular experience...structural inequities usually seem ordinary' (678).

The examples above are representations of other forms of violence as they overlap on matter of technicality. Significant in these examples is that human beings are the perpetrators as much as the victims of violence. This signification informs the task 
of this paper in the next section, where the paper demonstrates the ontological root of violence in human nature.

\section{THE ONTOLOGY OF VIOLENCE}

What more important subject is there but the study of human nature? ... An understanding of our nature...should help us live to the fullest or at least give us guidance (Pojman, 2005: xiii).

The field of philosophy that studies being in its totality is named ontology. While other fields of philosophical knowledge are concerned with various aspects of being, ontology takes interest in the nature qua nature of being. Properly conceived, therefore, ontology is the field of study that interrogates the nature and existence of being as an embodiment of physical and non-physical components (see Munn and Smith's Applied Ontology: An Introduction (2008); Coffey's Ontology or The Theory of Being: An Introduction to General Metaphysics (1914), Spear's Ontology for the Twenty First Century: An Introduction with Recommendations (2006), and Okoro's "Problems of Metaphysical Philosophy" (2011) for instance.). The significance of the field of ontology is what Pojman articulates as noted above; therefore, the discussion concerning the ontology of violence is an invitation to turn to the being that manifests reality of existence in totality, and this is no other being than that of human - a person.

In the Dialogues, we found a dualistic conception of person in Plato's thought. According to Plato, the soul (an immaterial entity) and the body (a material one) are the two components that make up a human person. Plato holds that the soul is the essence of the body and that makes the soul the most important component in human ontological make-up. In articulating this view, Annas (2003) writes:

Plato always takes as a starting point the thought that the soul is a different kind of thing from the body. Indeed, he is often regarded as a paradigm of dualism, the position that soul and body (in modern versions mind and body) are radically different kinds of entity. Further, Plato never doubts that when I ask what I, myself, really am, the answer will be that I am my soul, rather than my animated body (65).

Plato (1968) himself presents this in a dialogic conversation between Socrates and Glaucon in The Republic thus:

Socrates: .... It doesn't look to me as though it's a sound body that by its virtue makes the soul good, but the opposite: a good soul by its own virtue makes the body as good as it can be. How does it look to you?

Glaucon: It looks that way to me too

Socrates: If we gave adequate care to the intellect and turned over to it the concern for the precise details about the body, while we, so as not to talk too much, showed the way only to the models, would we be doing the right thing?

Glaucon: Most certainly (82). 
The soul in itself, Plato notes, has the calculating, spirited, and desiring parts that respectively perform the functions of (1) learning, (2) spiritedness, and (3) craving for worldly lusts. In this regard, Plato also presents the conservation between Socrates and Glaucon thus:

Socrates: Then it's in this way, my friend that we'll claim that the single man - with these same forms in his soul - thanks to the same affections as those in the city, rightly lays claim to the same names.

Glaucon: Quite necessarily

Socrates: Now it's a slight question about the soul we've stumbled upon, you surprising man, Does it have these three forms in it or not?

Glaucon: In my opinion, it's hardly a slight question. Perhaps, Socrates, the saying that fine things are hard is true.

Socrates: It looks like it. But know well, Glaucon, that in my opinion, we'll never get a precise grasp of it on the basis of procedures such as we're now using in the argument. There is another longer and further road leading to it. But perhaps we can do it in a way worthy of what's been said and considered before.

Glaucon: Mustn't we be content with that? It would be enough for me to present.

Socrates: Well, then, it will quite satisfy me too.

Glaucon: So don't grow weary, but go ahead with the consideration.

Socrates: Isn't it quite necessary for us to agree that the very same forms and dispositions as are in the city are in each of us? Surely they haven't come there from any other place. It would be ridiculous if someone should think that the spiritedness didn't come into the cities from those private men who are just the ones imputed with having this character, such as those in Thrace, Scythia, and pretty nearly the whole upper region; or the love of learning, which one could most impute to our region, or the love of money, which one could affirm is to be found not least among the Phoenicians and those in Egypt.

Glaucon: Quite so

Socrates: This is so, then, and not hard to know.

Glaucon: Surely not.

Socrates: But this now is hard. Do we act in each of these ways as a result of the same part of ourselves, or are there three parts and with a different one we act in each of the different ways? Do we learn with one, become spirited with another of the parts within us, and desire the pleasures of nourishment and generation and all their kin with a third; or do we act with the soul as a whole in each of them once we are started? This will be hard to determine in a way worthy of the argument

Glaucon: That's my opinion too. (114-115)

The affirmation of the soul or an aspect of it as craving for worldly lusts is to confirm that the inclination to be violent is ontologically rooted in human nature. The 
correctness of this assertion derives from our understanding of the meaning of "craving for worldly lusts". The meaning of the expression intricately connotes violence. In fact, this is equally ascertained in The Republic that

...the desiring - which is surely most of the soul in each person and by nature most insatiable for money - and they'll (the other two parts of the soul) watch it for fear of its being filled with the so called pleasures of the body and thus becoming big and strong, and then not minding its own business, but attempting to enslave and rule what is not appropriately ruled by its class and subverting everyone's entire life (Plato, 1968: 121).

As rightly stated by Plato, the desiring part of the human soul makes each individual exhibit conducts to bring about the satisfaction of its worldly lusts, and these conducts are without regard to preserve oneself or other selves. Thus, the craving for worldly desires as demanded by nature is an indication that violence is inexcusable in the pursuit or satisfaction of these desires.

There is no doubt that Plato's philosophical thought serves as a fundamental foundation for the rest of Western philosophy, if not global philosophy. Thus, his view is instructive in the discussion on the ontological root of violence. However, critics of pure immaterialist conception of human nature would disagree and raise the shortcomings of this claim by appealing to materialist conception of human nature. For instance, they may argue that since the presence of a soul cannot be empirically established, the claim about human nature as we have demonstrated above cannot hold. Such critics, like David Hume - a great philosopher of the empiricist tradition, conceive human nature in pure materialist terms.

Hume was largely influenced by the advancement of science of his time, and this made him reject the immaterialist conception of human nature that was prevalent then; in this respect, he submits that:

Nor ought we to think, that this latter improvement in the science of man will do less honour to our native country than the former in natural philosophy, but ought rather to esteem it a greater glory, upon account of the greater importance of that science, as well as the necessity it lay under of such a reformation. For to me it seems evident, that the essence of the mind being equally unknown to us with that of external bodies, it must be equally impossible to form any notion of its powers and qualities otherwise than from careful and exact experiments, and the observation of those particular effects, which result from its different circumstances and situations. And thou' we must endeavour to render all our principles as universal as possible, by tracing up our experiments to the utmost, and explaining all effects from the simplest and fewest causes, 'tis still certain we cannot go beyond experience; and any hypothesis, that pretends to discover the ultimate original qualities of human nature, ought at first to be rejected as presumptuous and chimerical (Hume, 1739: 6).

As shown, science and scientific inquiry became the standard of measurement of what is acceptable as useful or functional human knowledge during the time of Hume. Thus, on rejecting the immaterialist conception of human nature, he holds that the sensible component (which is the body and all the internal and external organs of the 
body) that constitutes a human person is the most important in explaining human action. According to him:

For my part, when I enter most intimately into what I call myself, I always stumble on some particular perception or other, of heat or cold, light of shade, love or hatred, pain or pleasure. I never can catch myself at any time without a perception, and never can observe anything but perception...setting aside some metaphysicians...,I may venture to affirm of the rest of mankind, that they are nothing but a bundle or collection of different perceptions, which succeed each other with an inconceivable rapidity, and are in a perpetual flux and movement (ibid: 134).

The primacy accorded to the body leads him to affirm that morality is neither divinely revealed nor determined by reason. As such, our passions - particularly our desires, Hume argues, determines end to which reason discovers only the means. In so far as it accords with a specific moral purpose, desire takes its direction from certain sentiments which, by the arbitrary constitution of our nature, arise in us when we observe human behavior (ibid: 233-248). In Hume understanding, every action which springs from desires is traceable to individual sentiment.

Our concern from the above is not whether human nature is purely constituted by a body or both a body and a soul as found in Plato, but that Hume acknowledges that human actions are naturally driven by desires, which in turn are dictated by sentiments. From this standpoint, it is shown that materialist account of human nature acknowledges the ontological origin of violence just as the immaterialist account. In fact, Hume adequately notes that violence cannot be explained away in the attainment of human desires when he submits that:

This requisite, then, to find some motive to acts of justice and honesty, distinct from our regard to the honesty; and in this lies the great difficulty. For should we say that a concern for our private interest or reputation is the legitimate motive to all honest actions; it would follow, that wherever that concern ceases, honesty can no longer have place. But 'tis certain, that selflove, when it acts at its liberty, instead of engaging us to honest actions, is the source of all injustice and violence; nor can a man ever correct those vices, without correcting and restraining the natural movements of that appetite (ibid: 250).

In the immaterialist and materialist conceptions of human nature as represented by Plato and Hume respectively above, what is consistent in their accounts - even though they opposed each other in many respects - is that human nature is ontologically intrinsic with violence, which is constantly orchestrated by desires. Human desires, therefore, remain the propeller of violence in human nature. The need to examine desires and how the craving for them propels violence arises, and this leads to Thomas Hobbes.

In Leviathan, Hobbes argues that a person is imbued with the right of nature, which is the liberty that each man has to make his own decisions about how to use his own power for the preservation of his own nature - that is, his own life - and consequently the liberty of doing anything that he thinks is the most apt means to that end (Hobbes, 1651: 72-93). Furthermore, Hobbes contends that all men are equal in that 
they all believe the same of themselves, and thus, their equal status fosters equality in their minds to realize their desires.

The result of this is that where two or more men desire what they cannot all have at the same time, they become distrustful enemies. This point is made clear in his submission that "the condition of man is a condition of war of everyone against everyone, so that everyone is governed by his own reason and can make use of anything he likes that might help him to preserve his life against his enemies" (ibid: 90). Life therefore, according to Hobbes, is an egoistic quest for the satiation of desires, and to this end, men will endeavour to destroy and subdue one another. This view is also articulated by Toffler (1990) when he notes that power is the reciprocal of desire, and that human desires are infinitely varied, anything that can fulfill one's desire is a source of power (30).

Hobbes further notes that it is in the nature of a person to seek glory, which is a form of desire. In articulating this view, Hobbes draws a comparison between persons and animals. According to him, a person is distinct from the animal in that he is concerned with glory, whereas for other animals there is no difference between the public and the private gain. In other words, a person is concerned with his gain as an individual, and in relation to that of other persons.

Consequently among men, Hobbes argues, there is envy, hatred, and war in the process of attaining desires; but among animals this is not the case because desire is not involved. It is therefore on three main grounds that men disagree and these are 'competition', 'distrust', and 'glory' (ibid: 87). Explaining each of these grounds, Hobbes submits accordingly as follows:

On competition, "because the way of one Competitor, to the attaining of his desire, is to kill, subdue, supplant, or repell the other. Particularly, competition of praise, enclineth to a reverence of Antiquity. For men contend with the living, not with the dead; to these ascribing more than due, that they may obscure the glory of the other." (ibid: 72),

On distrust, "Men that distrust their own subtilty, are in tumult, and sedition, better disposed for victory, than they that suppose themselves wise, or crafty. For these love to consult, the other (fearing to be circumvented,) to strike first. And in sedition, men being alwayes in the procincts of battell, to hold together, and use all advantages of force, is a better stratagem, than any that can proceed from subtilty of Wit" (ibid: 73$74)$,

And glory, "Vain-glorious men, such as estimate their sufficiency by the flattery of other men, or the fortune of some precedent action, without assured ground of hope from the true knowledge of themselves, are enclined to rash engaging; and in the approach of danger, or difficulty to retire if they can: because not seeing the way of safety, they will rather hazard their honour, which may be salved with an excuse; than their lives, for which no salve is sufficient” (ibid: 74).

An interesting work in addition to the classical literature considered above is the article by Robin Fox entitled "The Human Nature of Violence". In this piece, Fox sets out to "put violence into...scientific perspective" (Fox, 2016: 1). In doing this, he 
acknowledges that "one of the most common ways for scientists to look at human violence is to ask, what causes violence?” (ibid); and he considers it the wrong way as it is one of the reasons why scientists don't seem to get to any definite conclusion on the subject (ibid).

To pursue the task of putting violence into scientific perspective, Fox's starting point draws on an analogy of cause as against non-cause. According to Fox, scientists seek to investigate causes of abnormal state of affairs and not the causes of normal state of affairs; in other words, if a state of affair is normal, no one seeks to investigate why it is normal as well as the causes of its normalcy, but if it appears to be abnormal, the arsenal of investigation focuses on why it is so and what causes it to be. Fox stated this clearly when he submits that:

By and large, in the social and behavioral sciences as in life, we tend only to look for the "causes" of things we dislike. Thus, we look for the causes of divorce, but never for the causes of marriage; for the causes of war, but rarely for the causes of peace; for the causes of crime, but rarely for the causes of virtue; and for the causes of violence, but never for the causes of its opposite, however we phrase it - gentleness, perhaps. This is because we see things we dislike on analogy with diseases: they are by definition abnormal states. The normal state is marriage/peace/law/gentleness (or whatever), and this gets derailed in abnormal circumstances(ibid).

From the above, Fox goes on to state that humans considered violence as undesirable, which makes it an abnormal state that needs to be investigated for its causes, while non-violence as desirable, which makes it normal and need not be investigated for its causes. For Fox, to study violence with this orientation of the mind is what he calls "the disease approach" (ibid).

The disease approach assumes that violence is a disease which brings about unhealthy situation in individual and social existence; therefore as a disease, there is need to investigate it for its causes. And that non-violence, according to this orientation, is not a disease as it is desirable because it is the healthy state for individual and social existence hence, there is no need to investigate the causes.

However, Fox rejects this orientation of the mind or disease approach of the scientists; this is because he considers it as an assumption that treats violence as analogous to a disease. He thinks such an assumption is inappropriate for the phenomenon of violence is not the abnormal state of affair in human existence rather it is non-violence. He opines:

The assumption that violence is a disease is to make it the analog of diarrhea. But, what if it is in fact an analog of digestion, or of some sub process like metabolization, ingestion, or excretion? There is no future, in this case, in looking for its "causes" since it doesn't have any. It is just what the organism does as part of its routine of living. One can examine sequences within the routine and see where it fits (what its "functions" are); or, one can ask "ethological" questions about how it came to be there in the first place evolutionary and adaptational questions. What is it for? What are its adaptational advantages? What survival value does it give the organism? and so on. But "causal" questions are simply inapplicable. 
If we make this analytical mistake when looking at sequences of behavior involving violence at some point, then we will ask, What caused this violence to occur? and expend a lot of mental energy trying to find an answer on the analogy of, Why did diarrhea occur? But if we look at the same sequence in the ethological framework - as we do in "agonistic encounters" between animals of the same species, for example - we can predict fairly accurately when, in the escalation process, violence will occur. It is a natural, expectable, predictable, inevitable part of the process. It is not diarrhea. It is metabolization, if you like (ibid: 2).

In the submission shown above, Fox position is clear as regard violence as $a$ natural, predictable, inevitable part of the process of existence; just what the organism does as part of its routine of living. This position is instructive to understand violence, with its dynamics and variations in human existence, as a phenomenon that is ontologically rooted in human nature. This same conviction is noted in the submission of Addis that:

If our innate ability to reason and our occasional tendency to do so are part of the explanation of why we vaccinate ourselves against various diseases..., then there is no reason why an innate tendency to aggression...cannot be part of the explanation of why we...have a very high incidence of...conflict. It's a question of whether we want to explain why human beings fought each other on this particular occasion and not on that or rather why human beings fight each other at all. There must be the given organism with certain abilities and tendencies, desires, and impulses... (Addis, 1975: 124).

Without much ado, violence is not a disease as contextualized by Fox; rather it is a phenomenon that is ontologically rooted in human nature, and thus must always be given the required attention when undertaking studies on violence.

\section{CONCLUSION}

With the current state of affairs today where the phenomenon of violence is not only occurring on a large scale in both individual and social existence in every nooks and corners of the world, the need to bestow the required attention on the ontological root of violence in the studies undertaken to address it can no longer be undermined.

As we have demonstrated in this paper, the need for that required attention speaks volumes, though implicitly, concerning what have been done in the past, what is being done now, what is yet to be done, and what ought to be done if we truly desire peace and harmony within and among ourselves.

As a concluding remark, having demonstrated that violence is ontologically rooted in human nature, and as such, it is a normal phenomenon if exhibited by humans either in intra-personal or social relations. However, the inevitability of the quest to preserve self and social existence for the purpose of self-fulfillment and collective development makes non-violence imperative. Following from our discussion, it is evident that non-violence lacks ontological root in human nature, and this is also supported by Fox when he submits that: 
The real...question...is not why individual(s)... act so violently The real...question is how...cultures manage through initiation, intimidation, sublimation, bribery, education, work, and superstition to stop individual(s) from acting violently. (Fox, undated: 5)

Fox, in the above submission, is critical of non-violence as lacking ontological root in human nature; and as a result, it (non-violence) must have cause(s) which actually need to be investigated. To investigate the cause(s) of non-violence, Fox recommends that we turn to culture. The author of this paper shares the same view that culture is the harbinger of non-violence, and this is what we hope to explore in another paper. 


\section{BIBLIOGRAPHY}

Addis L., (1975) The Logic of Society: A Philosophical Study. Minneapolis: University of Minnesota Press.

Annas J. (2003) Plato: A Very Short Introduction. Oxford: Oxford University Press.

Armstrong, J.A., (1997) "Religious Nationalism and Collective Violence" in Nations and Nationalism, 3 (4). ASEN. Pp. 597-606.

Coffey P., (1914) Ontology or The Theory of Being: An Introduction to General Metaphysics. London: Longmans, Green and Co. $\begin{array}{ccccc}\text { Centers for Disease Control and Prevention, } & \text { (20 } \\ \text { http://www.cdc.gov/violenceprevention/youthviolence/ retrieved at 16:47 on the } 18^{\text {th }} \text { of March. }\end{array}$

Dahlberg L.L, \& Krug E.G. (200) "Violence: A Global Public Health Problem” in World Report on Violence and Health by Krug E.G, Dahlberg L.L, Mercy J.A, Zwi A.B, and Lozano R. (eds.). Geneva: World Health Organization. Pp. 1-21.

Fox R. (2016) "The Human Nature of Violence", retrieved from the website of Social Issues Research Centre http://www.sirc.org/publik/foxviolence5.html at 14:33 on the $24^{\text {th }}$ of March.

Friedman S.S (2001) "Feminism, State Fictions and Violence: Gender, Geopolitics and Trans-nationalism” in Communal/Plural, Vol. 9, No. 1. Pp. 111-129.

Ganley A.L., (2016) "Understanding Domestic Violence" retrieved from http://www.ecu.edu/tnwe/Endowment/Resources_files/improvinghealthcare_1.pdf on the 15th of April.

Gellner E.A (1954) "Reflections on Violence" in The British Journal of Sociology Vol. 5, No. 3 (Sept. edition) Pp. 267-271. London: Blackwell Publishing and The London School of Economics and Political Science. URL: http://www.jstor.org/stable/587073.

Hobbes T. (1651) Leviathan. 1909 edition by The Online Library of Liberty available at http://oll.libertyfund.org

Hume D. (1739) A Treatise of Human Nature. Reprinted from the Original Edition in three volumes and edited, with an analytical index, by L.A. SelbyBigge, M.A. (Oxford: Clarendon Press, 1896).

Kalyvas S.T., (2006) The Logic of Violence in Civil War. Cambridge: Cambridge University Press.

Keane J. (2004) Violence and Democracy. Cambridge: Cambridge University Press.

Mayer A.J., (2000) The Furies: Violence and Terror in the French and Russian Revolutions. New Jersey: Princeton University Press.

Munn K. and Smith B., (2008) (Eds.) Applied Ontology:An Introduction. Piscataway, NJ: Transaction Books and Rutgers University.

North D.C., Wallis J.J, \& Weingast B.R. (2009) Violence and Social Orders: A Conceptual Framework for Interpreting Recorded Human History. Cambridge: Cambridge University Press.

Okoro C., (2011) "Problems of Metaphysical Philosophy" in African Nebula, Issue 3, (June edition). 
Payne J, (2005) “The Prospects for Democracy in High Violence Societies" in The Independent Review, v. IX, n.4, (Spring edition), Pp. 563-572.

Plato (1968) The Republic. Second Edition. , Translated with Notes and an Interpretative Essay by Allan Bloom. USA: Basic Books. Press.

Pojman L. (2005) Who Are We? Theories of Human Nature. USA: Oxford University

Rutherford A, Zwi A.B, Grove N.J, \& Butchart A. (2007) "Violence: A Glossary” in Journal of Epidemiology and Community Health, Aug; 61(8): 676-680. BMJ Publishing Group Ltd.

Spear A.D., (2006) Ontology for the Twenty First Century: An Introduction with Recommendations. Saarbrücken, Germany: Institute for Formal Ontology and Medical Information Science (IFOMIS),

Toffler A, (1990) Power shift: Knowledge, Wealth, and Violence at the Edge of the $21^{\text {st }}$ Century. New York: Bantam Books.

Willem de Haan (2008) "Violence as an Essentially Contested Concept" in Violence in Europe: Historical and Contemporary Perspectives by S. Body-Gendrot, \&P. Spierenburg (eds.). New York: Springer 
Acknowledgements - the author benefitted the supports and contributions of the following institutions and individuals: The Turkiye Burslari for the provision of financial token each month during the fellowship research that produce this work, without which it would have been difficult to 'survive' in Turkey; the Department of Philosophy at Uludag University, Bursa-Turkey for the provision of the working environment and logistic supports for the work; the Lagos State University, Lagos-Nigeria (my employer) for granting the approval to be away from my duty post during the Fellowship; Prof. (Dr.) Abdulkadir Çüçen, the Chair of the Department of Philosophy at Uludag University and my wonderful host/advisor, for his interest and confidence in me and my work from the moment of applying for the Fellowship; Prof. Abolaji Adeniji, the sitting Dean (20142016) of the Faculty of Arts at the Lagos State University, for his 'faith' in my academic career; Prof. Olatunji Oyeshile of the Department of Philosophy at the University of Ibadan, Oyo-Nigeria and Prof. Danoye Oguntola-Laguda of the Department of Religions and Peace Studies at the Lagos State University, for instilling academic doggedness in me from their mentorship style; Dr. Ademola Fayemi and Mr. Oluwaseyi Oyekan of the Department of Philosophy at the Lagos State University for their constructive criticisms of this work; and finally, colleagues in the Department of Philosophy at the Lagos State University for moving the Department forward while I am away for the Fellowship; as well as Faculties and Research Assistants in the Department of Philosophy at Uludag University for their warm hospitality that I enjoyed during the Fellowship. 